University of Warwick institutional repository: http://go.warwick.ac.uk/wrap This paper is made available online in accordance with publisher policies. Please scroll down to view the document itself. Please refer to the repository record for this item and our policy information available from the repository home page for further information.

To see the final version of this paper please visit the publisher's website. Access to the published version may require a subscription.

Author(s): Ben Clift

Article Title: The political economy of the Jospin government

Year of publication: 2002

Link to published version:

http://dx.doi.org/10.1080/09639480220151154

Publisher statement: None 


\title{
The Political Economy of the Jospin Government
}

\section{Ben Clift}

Dr. Ben Clift, Politics \& International Studies, University of Warwick

\section{(B.M.Clift@Warwick.ac.uk)}

\begin{abstract}
This article explores the political economy of the French Socialist Party (PS), beginning with the neo-liberal U-turn of 1983. It then charts the re-evaluation of the PS's political economic foundations after the 1993 defeat, the rejection of the neoliberal 'pensée unique', and the rehabilitation of a broadly Keynesian frame of reference. The article goes on to explore how this shift has fed through into the Jospin government's policy and positions at both the national and international level. It explores aspirations to reinvent the EU as a Keynesian social democratic 'policy space', and at the national level, employment, macroeconomic, and structural policies.
\end{abstract}


This article explores the political economy of the Jospin government and assesses the approach known as left-wing Realism_(Réalisme de Gauche) as a potentially viable social democratic economic strategy. In order to fully understand Réalisme de Gauche, a firm grasp of the logic and limits of the economic strategy pursued by the PS in the decade after the U-turn of 1983 is necessary. The paper thus begins by exploring how the French Socialist Party internalised the U-turn of 1983, a pivotal moment in the political economy of French Socialism, heralding a neo-liberal shift towards competitive disinflation.

In the aftermath of the 1993 defeat, the party engaged in a process of auto-critique. A central theme of this auto-critique involved challenging of the pensée unique, which was the French translation of the dominant neo-liberal economic orthodoxy. This questioning of received economic wisdom engendered a new diagnosis of France's key economic problem, as well as a re-evaluation of the degree of volontarisme (state activism) possible in the international economic context of the 1990s. These two elements, the challenging of the dominant economic orthodoxy, and its corollary, the changing diagnosis of the economic problem, informed a particular reading of the implications of globalisation for social democratic economic strategy. The PS has been anxious to plot a course other than accommodation with neo-liberal orthodoxy on the assumption that 'there is no alternative.' There is an insistence upon the existence of room to manoeuvre a concept central to Réalisme de Gauche.

Réalisme de Gauche is built upon non neo-liberal economic foundations. The Jospin Government's neo-Keynesianism dovetails with the insistence upon the 'active state', and a critical engagement with globalisation. By conceiving of globalisation not as ineluctable but contested, the Jospin Government argues that a significant degree of state interventionism remains possible despite constraining global forces, based on a broadly Keynesian approach to the economy. The Government has demonstrated a commitment to 'the mobilisation of society towards a redefinition of public power national and international - in favour of job creation.' ${ }^{1}$ This involves, at both national and supra-national level a new approach to the key objective of employment creation.

In the final section - which looks briefly at employment policy, welfare policy, macro-economic policy and fiscal policy - we highlight the increased propensity of 
the Jospin government to explore activist possibilities, and also the accepted limits of such activism .

\section{Globalisation, Social Democracy, and Réalisme de Gauche}

The Mitterrand era began in 1981 with an ambitious counter-cyclical demand-boost and a dash for growth in the context of a world slump, termed by Hall, 'redistributive Keynesianism,2 However, within two years, external pressures, including significantly the conditions of EMS membership, and a series of financial crises undermined this macro-economic stance. Its reversal began as early as June 1982, but the coup de grace was administered in March 1983. ${ }^{3}$ The episode was widely interpreted, both within French Socialism and beyond, as a demonstration of the incompatibility of Keynesian social democracy and the new international political economic order of the post-Bretton Woods world.

The 'failure' of the Mitterrand experiment attested to the difficulties social democrats faced in attempting to control their national economic space in the new international political economic context. For some, this meant globalisation had rendered social democracy unworkable. ${ }^{4}$ More sober analyses recognised the impact of globalisation to be ambiguous. ${ }^{5}$ Globalisation neither 'mandates' nor 'prohibits' policies, but changes the structure of costs and opportunities of particular strategies. The room to manoeuvre for social democratic governments is (and ever was) quite small, but globalisation does not press upon actors irresistible policy formulation. Pierson's account insists upon 'complex interplay and feedback as politicians seek to anticipate markets and market actors seek to second-guess the politicians.' He insists that 'there are still choices to be made - even if these have become more expensive or more difficult to mobilize.' 6 There is real constraint, but also possible opportunity. We need not delve at length into the detail of that 'regime defining' choice of 1983, it has been done admirably elsewhere. ${ }^{7}$ However, it should be recalled that the so-called autre politique offered an alternative, rooted in the established referential of French economic policy-making.

That globalisation does not, in any straightforward manner, 'impose' financial discipline or neo-liberal policy agendas on social democratic governments lies at the 
heart of the political eocnomy of the Jospin government . Jospin asserts, 'we do not give in to the fatalistic idea that the neo-liberal capitalist model is the only one available. On the contrary, we can shape the world according to our values. ${ }^{8}$ Réalisme de Gauche suggests that globalisation does not preclude social democratic policy activism. Globalisation, according to Jospin, 'favours global growth, but is accompanied by growing of inequalities ... it liberates energies, but also negative forces which must be mastered. ${ }^{9}$ Regulation is, Jospin argues, the 'political globalisation' required in this new context; 'wherever there is a risk that only the law of the strongest may apply, or where private interests threaten the general interest, or where the search for short term profit undermines social justice and damages the environment, States must define the 'rules of the game', 10

Jospin's primary concern is with international financial regulation - where he urges the Bretton-Woods institutions to 'pursue their evolution' towards re-regulation of the international political economy, beginning with closer supervision of hedge funds and off-shore banking centres. Here Jospin repeats oft-cited calls for a Tobin Tax on volatile speculative capital flows, and urges the IMF, of all institutions, to engage in 'reflection' on encouraging greater 'viscosity' in the movement of capital as a source of stability. ${ }^{11}$ We could, Jospin notes, 'let the supposedly natural laws of economics guide the evolution of our societies, and in so doing, abdicate our political responsibilities. On the contrary, we could seek to re-orient the forces at work in the globalisation of economic activity.' ${ }^{12}$ No prizes for guessing which he favours.

For all the talk of voluntarisme and re-regulation, the 1983 U-turn nevertheless enforced upon French Socialists a recognition of external constraints and reduced room to manoeuvre in an international economic order where the 'embedded liberalism' of the Bretton Woods had ceased to insulate national economies. Emmanuelli and Chevènement referred to 1983 as 'notre Bad Godesberg' ${ }^{13}$ For all those who experienced at first hand the currency crises provoked by the mismatch between domestic economic priorities and strategy, and international economic context, 1983 was a salutary lesson into the limited nature of economic sovereignty. The 'realism' and pragmatism which underpins the political economy of the Jospin Government (notably in its 'consolidation' of public finances) is testament to the integration of these 'limits of the possible' into its frame of reference. 


\section{Competitive Disinflation}

What is most striking about the 1983 U-turn and the subsequent evolution of French Socialist macro-economic policy is the abandonment of the Keynesian paradigm as the dominant referential through which French Socialists analysed unemployment and macroeconomic policy and the relationship between the two. This engendered a shift of priorities in macroeconomic policy, relegating full employment to a distant future aspiration, and promoting tackling inflation to priority number one. The new hierarchy of priorities owed a good deal more to the (neo-liberal) new classical school than it did to Keynesian insights into the role of the state in maximising the level of employment within the economy. Competitive disinflation, as the new policy became known, was to an extent a reflection of changed international political economic realities. However, the new direction also reflected the singular reading of the implications of such changed realities by an elite in the capture of the 'pensée unique', the neo-liberal economic orthodoxy in its French articulation.

The logic of competitive disinflation is simple: 'under fixed exchange rates, a country with higher inflation loses competitiveness, and as a result demand for output falls. An increase in unemployment follows which makes inflation decrease sufficiently so that competitiveness is eventually re-established.' 14 The strategy was a crucial determinant of all aspects of economic policy from 1983 onwards. Competitive disinflation comprised three elements. First, the nominal stability of the franc fort, pegged to the DM. Second, wage restraint and wage discipline, initially through a deindexation of wages, which aimed to but tackle inflation, and also to shift added value from labour to capital, thereby improving profitability (and investment). The third priority was that of public deficit reduction, aiming to bolster financial credibility. ${ }^{15}$ Two aspects of competitive disinflation stand out: its emulation of German model, and the place of financial credibility (and the attendant accommodation to dominant neo-liberal orthodoxy) as its lynch pin. Monetary policy was no longer used as an instrument of reflation, activist fiscal policy was not countenanced, and 'Keynesian' inspired automatic stabilisers were partially 'turned off'. ${ }^{16}$ 
One Jospin Government advisor observed that 'the compliment to competitive disinflation was deregulation, to increase competition, and the competitivity of firms, and of the French financial system.' ${ }^{17}$ Microeconomic manoeuvres would bring market discipline to bear in order to improve the competitivity of French firms in the context of tight budgetary discipline and a strong currency. Such measures included the liberalisation of prices and the lifting of restrictions on foreign exchange transactions. Competitive devaluation, and its attendant 'moral hazard' problems, had been removed. Restructuring and adjustment was achieved through market mechanisms, with firms obliged to pay extremely close attention to their labour and 'social wage' costs and prices. Tackling unemployment had been one of the main priorities of economic policy between 1981 and 1983. After the U-turn, rising unemployment became instead the principle adjustment mechanism of the troubled French economy, about which the Government tacitly accepted it could do little.

Competitive disinflation 'worked' in the sense that credibility was eventually restored, and the competitiveness of French firms improved in the 1990s. But there were many unintended consequences. For example, whilst wages were brought down very significantly, reducing production costs, the dampening effect this would have on demand was not factored in to the model. The flaws of competitive disinflation are more damningly demonstrated by its impact on French economy and society in the 15 years following the U-turn, which saw structural unemployment rocket. ${ }^{18}$ Problems were compounded by the 'asymmetric dependency' of Franco-German economic relations in the post-reunification period. Germany decided to finance reunification through European borrowing, and, accordingly, set very high interest rates, which French rates were constrained to shadow, discouraging productive investment. This further crippled France’s already sluggish growth.

The strategy of competitive disinflation was clearly running counter to the declared justification of long-term job creation. Employment priorities suggested the urgent need for a reduction of interest rates, and a devaluation of the Franc vis-à-vis the Deutschmark. However, employment was so low on the macroeconomic hierarchy of priorities, and the competitive disinflation referential with its attendant sound money ethos was so dominant, that when the Germans proposed a re-alignment of parities within the EMS, revaluing the Mark, Bérégovoy refused. ${ }^{19}$ The market medicine was 
killing the patient. Austerity dampened demand, meanwhile persistent high unemployment produced 'hysteresis' effects, with low activity and slow capital accumulation triggering bankruptcies, and destroying productive capacity. The structural unemployment rate was 'ratcheted' up. This scenario obtained between 1983, when unemployment stood at 8.3 per cent, until 1997, when it exceeded 12.6 per cent: 'The strategy followed has been, quite simply, to achieve disinflation and increased competitiveness through higher unemployment.' 20

\section{Shifting the Policy Paradigm: From Pensée Unique to Réalisme de Gauche}

Electorally, the manifest failure of a decade of Socialist Government to make any impression on the soaring unemployment figures was devastating. This, acting in tandem with widespread disdain for a sleaze-ridden Socialist elite, heralded the biggest defeat in the history of French Socialism in $1993 .{ }^{21}$ The failure of the Bérégovoy government, like those before it, to deliver on its pledge to reduce unemployment led to a re-evaluation of Socialist economic strategy. Too much, it was felt, had been sacrificed at the altar of economic orthodoxy, with resultant gains in financial credibility and profitability, but not jobs.

The set the tone for the message Jospin repeated in his 1995 Presidential manifesto:

'We must learn the lessons of the past, in order to instigate the reorientations of economic policy which today are necessary and possible without increasing public deficit, nor putting our currency, our external balances, or the competitivity of our firms in peril. I reject the idea that the state is powerless, and believe that it should deploy all its capacities to aid job creation. ${ }^{22}$

Jospin couches his scepticism about neo-liberal orthodoxy in 'realist' terms. Certain parameters for action, such as a commitment to monetary stability, are accepted, given the context of an interdependent and relatively open economy and deregulated financial markets. However, the precise location of the limits of the possible is contested. The need to be seen to be credible by investors and speculators does not rule out policy activism. Thus questioning of the dominant economic orthodoxy informs the philosophical foundation of the new strategy; an insistence upon the 
existence of 'marges de manoeuvre', and a belief that all the means of tackling unemployment have not yet been explored. The existence of room to manoeuvre was demonstrated, for example, by the $15 \%$ tax levied on non-reinvested profits by the Jospin government in 1997, justified in terms of the need to reduce the budget deficit in order to meet the convergence criteria. $^{23}$ In calling for the less restrictive conception of the convergence criteria, ${ }^{24}$ Moscovici questions 'the erroneous conviction that the $3 \%$ level is an absolute barrier, separating monetary virtue from vice'. ${ }^{25}$ A similar approach has subsequently been taken to the Growth and Stability Pact (see David Howarth's article in this issue)

With the calling into question of competitive disinflation came also the questioning of its theoretical foundations, and the canon from which they are drawn. The Jospin Government was keen to renew with the influence of economic thought of broadly Keynesian origin within the PS. Although remaining within the framework of a commitment to stability, the advocated strategy has a Keynesian feel to it. Firms must anticipate 'solvent' levels of demand - which presupposes mass consumption, and therefore higher salaries. This explains the commitment to limited redistribution from capital to labour, particularly towards those lower earners with a higher propensity to spend, albeit tempered by an appreciation of the importance of the profitability and competitiveness of firms. Whilst careful to point out that this is not a return to oldstyle Keynesian policies, the different ideological suppositions under-pinning this different view of the economy are explicitly highlighted. ${ }^{26}$

The challenging of the dominant economic orthodoxy, and its corollary, the changing diagnosis of the economic problem, inform a particular reading of the implications of globalisation for social democratic economic strategy - Réalisme de Gauche. Jospin rejects 'finding a middle way between social democracy and neo-liberalism'. The idea of capitalism as, 'a force that moves, but does not know where it is going' informs the view that, 'the regulation of capitalism is essential and requires an active state.' 27 The French state, institutionalising the values of solidarity, co-operation and inclusion should act, it is argued, as a counterweight to the market to promote social cohesion. Greater efficiency is called for in state redistribution policies, necessitating fundamental reform of the tax system 'to increase social justice, ceasing to privilege capital in order to favour labour, and to preserve solidarity.' ${ }^{28}$ Thus Réalisme de 
Gauche reconciles an enduring dirigiste dimension with growing enthusiasm for the market. As Jospin notes, 'the concept of volontarisme (or an active state) does not set up the state in opposition to the market, but instead creates a new alliance between the two.' 29

At the heart of Réalisme de Gauche is a more critical engagement with the neo-liberal view of capitalist market economy, and an unequivocal attachment to a recognisably social democratic role for state. This rejects the orthodox assumption that 'there is no alternative', and is predicated on Jospin's critical engagement with globalisation outlined above. Accordingly, the Jospin Government has developed a 'dual-level' approach to employment strategy emphasising expanding 'room to manoeuvre' through European economic policy co-ordination in tandem with domestic voluntarisme.

In the wake of the 1983 U-turn, and the Fontainebleu summit which saw the process of European integration actively pursued with a renewed vigour by Mitterrand, the PS's internationalism underwent a thorough Europeanisation. This Europeanisation entailed a realisation that France is an integral part of the EC, and given the degree of interdependence of the European economies, the French nation state must be conceived as intrinsically part of a greater European whole. President Mitterrand's lead on Europe was also a means of filling the 'gap' left by the end of transcendental rhetoric and the impact of governing constraints on maximalist programmes. The party needed to regain its sense of engagement in social transformation and rediscover some doctrinal and programmatic coherence. Enthusiasts saw advancing European construction as an appropriately large-scale reformist project to substitute for the policies of Projet Socialiste.

Given the constraints on national economic management which preclude Keynesian macro-policy approaches, international co-operation and co-ordination is an increasingly important component of social democratic economic strategy. Thus it is increasingly at the European level that French Socialists have sought to rearticulate Keynesian insights, and resolve the tensions between globalisation and social democracy. The conviction is widely held that European co-operation and integration offers the only viable 'response' to globalisation. This pursuit of 'public 
goods' unattainable at the national level at EU level has been a central strand of French Socialist thinking in recent years. It is exemplified in the 'Euro-Keynesian' aspects of the Delors White Paper, which advocates a co-ordinated European economic expansion, boosting employment across the continent. ${ }^{30}$

The Jospin Government has championed such reforms, and sought to institutionalise more thoroughgoing employment goals within the process of European construction. Jospin seeks a new path to full employment, a dual-level strategy combining national level reforms with a re-orientation of the process of economic integration towards greater emphasis on employment. The aim is for a negotiated rebalancing of the policy mix, hoping to generate co-ordinated fiscal, monetary, and structural policies across the EU to be geared towards jobs and growth. The strategy is one of continued critical engagement from within, arguing at every turn for reorientations, such as a European Jobs and Growth Pact (at Amsterdam), a European Growth fund (at Portschach) and the embryonic formulation of a common European employment strategy (at the Luxembourg and Cardiff jobs summits).

\section{The Policy Profile of the Jospin Government: Domestic voluntarisme?}

At the national level, Réalisme de Gauche involves an insistence that room to manoeuvre does exist, and therefore policy activism is possible. Despite the constraints of an increasingly open economy, the Jospin Government has sought to 'rehabilitate' activist economic policy. A broadly Keynesian rationale ${ }^{31}$, stimulating purchasing power to increase the growth potential of the French economy, facilitating a boost in consumption and investment, informs a set of redistributive fiscal measures, as well as social exclusion measures, all framed in egalitarian terms. We now demonstrate the coherence of the Jospin government's approach in the fields of Welfare, Employment and Macro-economic policy.

Jospin's egalitarian rhetoric, although not always matched by policy outcomes, should be set against the backdrop of French welfare provision which has sustained an evergrowing source of redistribution in terms of social welfare. France's welfare state is the largest outside Scandinavia. Social security spending was $30 \%$ of GDP in $1995 .{ }^{32}$ Welfare policy plays a role in employment policy-but its fundamental aim is 
redistribution. The logic underpinning family allowances in France, for example, has shifted markedly in the last 20 years towards redistribution from wealthy to poor. ${ }^{33}$ The Jospin government's biggest welfare achievement has been the establishment of universal health cover. This makes health cover available to the disadvantaged free of charge, as Levy notes, 'by providing free supplementary health insurance on a meanstested basis to an estimated 6 million people (those living on less than 3500 francs per month for a single individual, 7700 francs for a family of four). ${ }^{34}$ That said, the Jospin government's attempts to redistribute in favour the poor is not easy to reconcile to a complex social insurance based French welfare state which has tended to prioritise contribution-based income maintenance above universalistic redistribution. ${ }^{35}$

In terms of employment policy, the Jospin Government sees the state's role as the guarantor of employment. The Party's reflection on its objectives in the decade ahead recently affirmed a strong commitment to establishing 'a society of full employment .. and the amelioration of the quality of employment. ${ }^{36}$ Accordingly, its activist employment policy informs a multi-pronged strategy which involves a state regulated reduction of the working week, the creating of jobs for urban and environmental regeneration, and shifting incentives in the labour market through fiscal policy. Most of the tax and social security reductions enacted by the Jospin government (in particular tax reductions on low or modest incomes) have had the dual aim of assisting employment creation as well as boosting purchasing power. Nowhere is the state's enduring role in the job creating strategy more in evidence than in the Jospin government's state orchestrated shift to a 35 hour week, aiming to reduce unemployment and to have a redistributive effect between labour and capital. The French law emphasises job creation, with state aid in the form of reductions in social security contributions offered to firms creating new jobs as a result of the reduction of the working week. The fixed levels of these state financial aids means that they will be relatively more generous for lower earners. These themes are developed in more detail by Susan Milner in the current issue.

The active labour market measures adopted, in conjunction with a favourable macroeconomic context provided by a 'soft' euro, have enabled the Jospin government to claim conspicuous successes on the employment front. Unemployment 
fell below 10 per cent in 2001, with a total of 2,371,300 unemployed-down from 3.2 million (12.5 per cent) when Jospin took office. On current trends, unemployment is set to dip below 9 per cent by the end of next year. ${ }^{37}$ Jospin now talks of the creation of a full employment society_-something no one on the French left has done since the dramatic policy U-turn of 1983.

What about macro-economic policy? This is described by one advisor of the Jospin Government as ‘post-Keynesian’ . The Jospin Government prioritises 'redistribution in favour of employment'. This involves fiscal redistribution in favour of lower earners to raise purchasing power, including tax reductions increasing households' disposable income. The Government actively advocates growth through expansion of demand, and the redistributing of added value in favour of salaried workers. A key budgetary objective of Jospin's governments has been to reinforce growth through tax and social security reductions to assist employment creation and boost purchasing power. As Muet notes, 'macroeconomic policies are essential and play a key role in stimulating growth and jobs ... structural policies are only efficient in a context of rising demand. It is pointless to tackle unemployment with structural policies alone. ${ }^{38}$ Budgetary reflation has been abandoned, but other measures, drawing on other Keynesian insights, are retained. The Jospin Government is keenly aware of the need to redistribute to lower income brackets with a higher propensity to spend as a means of keeping demand buoyant. ${ }^{39}$

The Jospin Government has certainly achieved some redistribution, raising the SMIC (minimum wage) by 4 per cent (well above the rate of inflation) on entering office. In December 1998, the Revenu Minimum d'Insertion and two similar minimum income guarantees were raised by 3 per cent, backdated a year. While redistributing wealth to low and non-earners hinted at the 'neo-Keynesianism' of Réalisme de gauche, both redistribution and the consumption boost were kept within quite tight limits in the face of macroeconomic constraints. Indeed, Jospin's pragmatic realism held back SMIC increases to the legal minimum of 3.2 per cent in 1999 and 2000, despite a context of strong economic growth.

Reform to and augmentation of the role of the Contribution Sociale Généralisée (CSG) have been conspicuous mechanisms of the Jospin Government's redistributive 
agenda. This is part of a wider attempt to shift the logic of welfare funding in France. The 1998 budget increased the CSG - applied to all earnings and not just wages from $3.4 \%$ to $7.5 \%$, and at the same time decreased workers contributions to health insurance from $5.5 \%$ to $0.75 \%$. According to Levy, 'although the fiscal yield was unchanged, the reform provided the average worker with a $1.1 \%$ gain in purchasing power; conversely it added to the tax bill of those (primarily, the affluent) who derive earnings from property or capital. ${ }^{40}$ Furthermore, the 2000-2003 budget reforms will make the CSG more progressive, reducing the CSG for low earners, and exempting those on the minimum wage from the CSG by 2003. There has also been 'progressive' reform to make the Solidarity Tax on Wealth (ISF) more effective. It was increased in the 1998 budget, its coverage was extended to close a number of loopholes, and a new band introduced in the 1999 budget. $^{41}$

More recently, income tax cuts in March and September 2000 disproportionately favoured low and non-earners. ${ }^{42}$ The reorganisation of income tax from 2000 to 2003, including a reduction in income tax rates for all income bands-including the highest — seem to have a more populist logic, given the 'war chest' provided by economic growth, and the proximity of the presidential election. That said, the Jospin government has made income tax more progressive, with the lightening of the load targeted particularly at the lower brackets. ${ }^{43}$

The context of these redistributive measures was a more generalised lightening of the fiscal load, in particular, on small and medium-sized firms. Illustrating the pragmatism and commitment to macroeconomic stability of the Jospin Government, much of the redistributive reform has been achieved through fiscal 'cost-shuffling'. The 1998 budget, for example, involved a 'revenue neutral reform that shifted the burden from low-income groups to high-income groups (leaving business unaffected). ${ }^{44}$ Thus, redistributive commitments and egalitarian aspirations are tempered by 'realist' considerations, 'redistribution does not override other considerations ... for the fruits of economic growth to be redistributed, there must first be growth.' Such fruits have permitted tax cuts across the board. That said, progressive fiscal policy is constrained, not least because, 'in the new global market we must ... ensure that our production base is competitive. ${ }^{, 45}$ 
The Jospin Government is perhaps best conceived as 'reluctantly post-Keynesian'. Their 'post-Keynesianism' owes more to the constraints of the Growth and Stability Pact given membership of the Euro than to a changed analysis of the economy. Even here, the Jospin Government seeks to explore any 'room to manoeuvre' created by flexible interpretation of the 'Growth and Stability' pact ${ }^{46}$, benignly viewed as a credibility-bolstering 'hedging' rather than a disciplinary 'binding' mechanism.

Nevertheless, the 'external constraint' of the global political economic context engenders close attention to the grandes équilibres of the French economy. Thus the 'medium term consolidation of the public finances' (moves towards budget balancing) remains a central objective. This is understood to necessitate public deficit reduction (down from 3.5\% of GDP in 1997 to 1.4\% in 2002), a reduction of public spending as a proportion of GDP (from $55 \%$ in 1999 to $52.3 \%$ in 2001), and a reduction of debt as a proportion of GDP (59.3\% of GDP in 1997, down to $56.3 \%$ in 2002). ${ }^{47}$ Such 'consolidation' does not mean the Jospin Government has ceased to be social democratic, or has 'swallowed' neo-liberalism. Rather, as Dyson notes, the French Socialists 'sought to draw a line between embracing rules of 'sound' public finance and money and taking on the whole apparatus of neo-liberal and monetarist policy discourse.’ 48

Returning to the earlier point about social democracy and globalisation, some of the changed parameters of economic policy-making relate to changed realities of the global economy. It is important to draw distinctions between different elements of economic policy packages, and recall that whilst certain aspects may be closely linked to neo-liberal policy agendas, others are perfectly compatible with social democratic ones. Whilst the credibility demanded by financial markets does have ideological dimensions, often rooted in a broadly neo-liberal view of economic activity, it is to an extent a reflection of changed economic realities. The Jospin Government faces the dilemma, common to all centre-left governments, of the desire to exercise discretion to pursue social democratic objectives, tempered by the need for government policies to be perceived as sound and sustainable. Within a framework of a commitment to macro-economic stability, there remains room for manoeuvre over the degree of 'orthodoxy', as well as a whole range of other economic policy tools that may be exploited to prioritise 'social democratic' goals. 
The key point is that securing credibility through stability-centric macro policy stances is compatible with a wide range of different priorities in other areas of economic policy. Furthermore, such a commitment to stability does not condemn a social democratic government to budgetary immobilisme. The Government accepts that there are clear limitations on macro-economic policy, not least arising from membership of the Euro. Equally, however, the Jospin Government's macro economic policy is not totally post-Keynesian.

\section{Conclusion}

To what extent does the experience of the Jospin Government represent a new model of social democracy? If nothing else, this episode undermines the hubris surrounding the 'end' of social democracy, and indeed of Keynesianism. Jospin cites, 'determined efforts to combat unemployment, through economic growth, a negotiated reduction in the working week to 35 hours and a broad-ranging plan for youth unemployment ... laws we have passed to combat all kinds of exclusion and to establish universal health cover' as evidence of his Government's 'neo-Keynesian' approach. ${ }^{49}$ In macroeconomic policy, leeway, provided in part by the position in the economic cycle, has facilitated a partially activist fiscal policy, achieving limited redistribution to both working and non-working poor. That said, the Jospin Government has been partially constrained, despite flexible interpretation, by the Growth and Stability Pact to limit activist intentions.

In employment policy, the Jospin Government, whilst accepting the argument for increased temporal flexibility, rejects the idea that 'globalisation' necessitates increasing wage flexibility or separation rates. Instead, their labour market reforms involve prioritising negotiation and redistributing available work. France's embedded welfare and labour market institutions continue to engender lower levels of wage inequality, and higher minimum standards than most of her main comparators. Such egalitarian commitments have been clearly affirmed since 1997, notably with the introduction of universal health cover. Réalisme de gauche has combined an active role for the state, relatively generous welfare provision, limited labour market 
flexibility, neo-Keynesian macroeconomics and enthusiasm for EU macroeconomic co-ordination, through which the Jospin's Government has sought to entrench and defend the European Social Model, and boost jobs and growth at the EU level.

Some major issues surrounding retrenchment of the French welfare state, such as pension reform, remain outstanding (and intractable) problems ahead. However, perhaps a greater threat to the 'model' than this is the lack of a secure governing coalition underpinning Jospin. Unlike, say, Swedish Social democracy, the French Left has never enjoyed a reliable cross-class basis of support. Jospin himself concedes that the French Socialists have never been a mass party; 'we do not have in France a strong tradition of negotiation and social dialogue ... We can experience wide-scale electoral successes followed by major setbacks because we do not draw our support from specific social foundations. ${ }^{50}$ Thus the viability and sustainability is threatened not by any internal contradictions, but by the permanent electoral frailty of French Socialism, which could undermine many of the achievements of the last five years.

\section{Notes and References}

${ }^{1}$ MOSCOVICI, P. (1997) L'Urgence: Plaidoyer pour une autre politique (Plon: 1997), p. 55.

${ }^{2}$ HALL, P., Governing The Economy (Polity, 1986)

${ }^{3}$ Notably by Peter Hall in Governing The Economy

${ }^{4}$ GRAY, J., After Social Democracy (Demos: 1996); GRAY, J., False Dawn

(Granta: 1998)

${ }^{5}$ HELD, D., MCGREW, A., GOLDBLATT, D. and PERRATON, J., Global

Transformations, (Polity: 1999), PIERSON, C., Hard Choices: Social Democracy in $\underline{\text { the } 21^{\text {st }}}$ Century (Polity: 2001) 
6 JOSPIN, L., ‘Ma vision de l’Europe et de la mondialisation’ Notes de la Fondation Jean-Jaurès (2001) 25.

${ }^{7}$ MUET, P-A. \& FONTENEAU, A., La Gauche face à la crise (Presses de la FNSP, 1985); CAMERON, D., 'Exchange Rate Politics in France 1981-83: The Regime Defining Choices of the Mitterrand Presidency’. In A. DALEY (ed.) The Mitterrand Era (Macmillan: 1996), pp. 56-82.

${ }^{8}$ JOSPIN, L., Modern Socialism (Fabian Society: 1999), p. 10.

${ }^{9}$ JOSPIN, Modern Socialism, pp. 33-34.

${ }^{10}$ JOSPIN, Modern Socialism, p. 36.

${ }^{11}$ JOSPIN, Modern Socialism, pp. 37-8

12 JOSPIN, Modern Socialism, p. 44.

${ }^{13}$ In the post-mortem of the 1993 defeat. See PS Info, 544 (1993).

${ }^{14}$ FITOUSSI, J.-P., Competitive Disinflation (Oxford University Press: 1993)

${ }^{15}$ LORDON, F. , 'The Logic and Limits of “Désinflation Competitive”’ Oxford

Review of Economic Policy 14: 1 (1998), pp. 96-113.

16 FITOUSSI, Competitive Disinflation, p. 17.

${ }^{17}$ Interview with DANIEL VASSEUR 17/12/97.

${ }^{18}$ FITOUSSI, J-P., Le Débat Interdit: Monnaie, Europe, Pauvreté (Arléa:1995).

${ }^{19}$ FRIEND, J., The Long Presidency: France in the Mitterrand Years (Westview Press: 1998), pp. 189-190. See also DYSON, K and FEATHERSTONE, K., The Road To Maastricht (Oxford University Press: 1999), pp. 213-215.

${ }^{20}$ FITOUSSI, Competitive Disinflation, p. 18. See also BLANCHARD, O-J. and MUET, P-A., 'Competitiveness Through Disinflation: An Assessment of French Macro-Economic Strategy’ Economic Policy 16 (1993), pp. 12-50. 
${ }^{21}$ HABERT, P. PERRINEAU, P. and YSMAL, C. (eds.) Le Vote Sanction : Les Élections législatives des 21 et 28 mars 1993 (Presses de la FNSP: 1993)

22 JOSPIN L., ‘1995-2000 : Propositions pour la France’ (Parti Socialiste, 1995)

${ }^{23}$ DUPIN, E. Le Disciple - ou les dix leçons que Jospin a appris de Mitterrand (Plon: 1998), p. 203.

${ }^{24}$ MOSCOVICI, L’ Urgence: Plaidoyer pour une autre politique, p. 10

${ }^{25}$ MOSCOVICI, L’ Urgence: Plaidoyer pour une autre politique, p. 95.

${ }^{26}$ MOSCOVICI, L’ Urgence: Plaidoyer pour une autre politique, pp. 59-60.

${ }^{27}$ JOSPIN, Modern Socialism pp.4, 8 \& 7.

${ }^{28}$ Vendredi (3 Août 1996)

${ }^{29}$ JOSPIN, Modern Socialism, p. 11.

30 DELORS, J., 'White Paper on Growth, Competitiveness and Employment'

(European Commission, 1993); DELORS, J.,_Comments and Proposals for a new

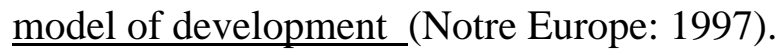

31 The notion of 'Keynesianism' as employed here refers not to precise mechanisms of fine or coarse tuning, or to deficit financing, but to the broader insights into the relationship between the state and the economy, and the role of the state in ensuring security of employment.

32 LEVY, J. (2001) 'Social Policy in the Age of High Unemployment'. In A.

GUYOMARCH, (ed.), Developments in French Politics 2 (Palgrave: 2001), p. 199.

${ }^{33}$ LEVY, 'Social Policy in the Age of High Unemployment', p. 197.

${ }^{34}$ LEVY, 'Social Policy in the Age of High Unemployment', p. 198.

35 PALIER, B. ' “Defrosting” the French Welfare State', West European Politics 23: 1 (2000), pp. 113-136. 
${ }^{36}$ PARTI SOCIALISTE 'Pour de nouveaux choix de société', p. 38. The text was presented at the National Council of 17 November 2001.

${ }^{37}$ In the first quarter of 2000, 140,000 new jobs were created in the private sector. In total, in the previous 12 months, 430,000 jobs were created. These increases are spread across all sectors, with service by far the most dynamic. See GRAHAM, R., 'France: Jobs Materialise at a Healthy Rate’, Financial Times, (14 June 2000). ${ }^{38}$ MUET, Achieving Full Employment, p.10.

${ }^{39}$ Purchasing power as a prop of household revenue increased by 16\% from 1997 to 2002 (the best 5 year performance in over 20 years). 'Projet de Loi des Finances pour 2002’ Les Notes Bleues de Bercy (Numero hors serie:2002), p. 11.

${ }^{40}$ LEVY, J. 'France: Directing Adjustment?' in F. SCHARPF and V. SCHMIDT, Welfare and Work in the Open Economy: Volume Two (Oxford University Press: 2000), pp. 337-344.

${ }^{41}$ See OFCE L’Économie Française (La Découverte: 1999), pp. 19 \& 63. See also ‘Projet de Loi des Finances pour 2002’ Les Notes Bleues de Bercy (numero hors série: 2002), p. 20.

${ }^{42}$ In March 2000, a 10 per cent income tax cut was introduced for $5 \mathrm{~m}$ lower earners, and 650,000 particularly low earners were exempted from taxation altogether. Financial Times (23 March 2000). In September 2000, income tax was further reduced. Libération (31 August 2000)

43 'Projet de Loi des Finances pour 2002’, pp. 21-22. It should be recalled, however, that income tax represents a lesser proportion of the total tax take in France (24\% in 1999), than in, say, the UK (39\% in the same year).

${ }^{44}$ LEVY, J. ‘France: Directing Adjustment?’, p. 340.

${ }^{45}$ JOSPIN Modern Socialism, p. 11. 
${ }^{46}$ Thus, the PS argued, in the event of a down-turn in the economic conjuncture, spending should not be changed even if it were to slightly overshoot the 3 per cent deficit target, allowing macro-policy to counter a crisis of insufficient demand as part of the job creating strategy. PARTI SOCIALISTE, Changeons L'Avenir, (Parti Socialiste: 1997); MOSCOVICI L’Urgence: Plaiydoyer pour une autre poltique, pp. 96-98.

47 'Projet de Loi des Finances pour 2002', pp. 6 \& 113.

${ }^{48}$ DYSON, K ‘Benign or Malevolent Leviathan? Social Democratic Governments in a Neo-Liberal Area’ Political Quarterly, (1999 ), p. 202.

${ }^{49}$ JOSPIN Modern Socialism, p. 6.

${ }^{50}$ JOSPIN, Modern Socialism, p. 5. 